DOI: 10.14526/2070-4798-2019-14-3-59-64

\title{
Theoretical and practical aspects of technical University students physical health formation
}

\author{
Ildus G. Gibadullin*, Aleksandra Yu. Anisimova, Mikhail E. Ryabov, Yuriy A. Melnikov \\ M.T. Kalashnikov State Technical University \\ Izhevsk, Russia \\ ORCID: 0ooo-0o01-6386-1121, ffkis@istu.ru* \\ ORCID: 0000-0002-5899-91, ffkis@istu.ru \\ ORCID: 0000-0003-0074-1338, ffkis@istu.ru \\ ORCID: 0000-0003-1751-8327, ffkis@istu.ru
}

\begin{abstract}
The article considers the aspects of technical University students physical health formation. Researches of functional groups dynamics formation for physical education at the University clearly reflect the maximum level of functional deviations in the state of students health. There is room for variation in the ratio of functional groups in quantitative terms due to the reduction of functional abnormalities. On the one hand, the growth rate of functional abnormalities and the frequency of chronic abnormalities increases. On the other hand, the inclusion in the daily life of students of various programs of physical activity leads to an increase in the proportion of students belonging to the main and preparatory groups. The factors negatively influencing the state of health in the conditions of higher education and adaptation of students to the conditions of study at the University are revealed. Materials and research methods. The research in dynamics of students groups decades formation in the directions of carrying out occupations on physical education as the main, preparatory, special group usual and training medical physical culture is carried out. A questionnaire survey of students to identify the causes that affect the health of University students, determined the rank structure of external and internal factors. Results. There was an increase in the growth rate of functional abnormalities and the frequency of chronic diseases. The inclusion in the daily life of students various physical activity programs leads to an increase in the proportion of students belonging to the main and preparatory groups. The rank structure of factors influencing the health of the first-year students in the process of adaptation to the University life is revealed. Conclusion. Research of functional groups formation dynamics in the conditions of higher education demands continuation of similar work for the purpose of students physical health control. The study of the factors affecting the health of students rank structure in the process of adaptation to University life, allows to adjust the process of physical health formation. Students have a low level of knowledge about the methods of HLS and the role of physical culture and sports.
\end{abstract}

Keywords: students, physical health, factors, rank structure of causes, functional groups.

For citation: Ildus G. Gibadullin*, Aleksandra Yu. Anisimova, Mikhail E. Ryabov, Yuriy A. Melnikov. Theoretical and practical aspects formation of physical health of students of technical University. Russian Journal of Physical Education and Sport. 2019; 14(3): 59-64. DOI: 10.14526/2070-4798-2019-14-3-59-64

\section{INTRODUCTION}

Modern health problems of students constitute a fundamental basis for the formation of health potential in their future professional activities. Healthy people are an indicator of the country's success and a factor of the nation's security. In this regard, in recent years we have witnessed a rapid growth of interest in physical culture of various directions, considering the health of young people in close relationship with the level of physical activity. The state policy of the country is directed on reorientation of physical culture on strengthening of rising youth health. Such a program should work at all levels of children physical education. Despite the fact that the state pays much attention to improving the health of the population, every year there is a decrease in health indicators manifested in the physical fitness of students.

Students are yesterday's pupils. From year to year in educational institutions a smaller number of healthy students are recorded. It is noted that every second student has morphofunctional abnormalities, and about $40-45 \%$ of students suffer from chronic diseases. This situation can be associated with socio-economic factors, ecology, changes in the educational process, aimed at increasing the mental load. The lag of the schoolchildren and students physical education targeted program is noted. It is well known that human health depends on the level of physical activity. Today, the hypodynamic regime 
of modern schoolchildren reaches 90\% of the school time, and this trend is becoming characteristic of universities.

The analysis of literary sources shows that the solution to the problem is to create innovative methods aimed at increasing the need of students for regular physical activity.

Thus, V. K. Balsevich believes that the creation of different orientation technologies (health, conditioning, sports-oriented, training, etc.) allows to increase the range of free choice of motor activity. The author considers it necessary to interest those engaged in various forms of motor activity, starting from the school bench $[1,2,3]$.

G. A. Gavronina (2007, 2008) developed and experimentally justified the programs of motor activity for students of a special medical group, proving the need to create a technology of rehabilitation and training taking into account medical limitations (limitations on medical indicators) $[4,5]$.

M. M. Kolokoltsev (2014) considers ways of including effective training motor regime in physical education of foreign students [6, p. 18-20].

R. F. Kusyakova $(2008,2014)$ experimentally proved the effectiveness of the methodology implementation for the development of coordination abilities by means of classical dance as a basis for the formation of the students motor activity culture $[7,8,9]$.

S. G. Nagovitsyn (2010), considering physical culture in General cultural and professional training of non-physical education institutions students, emphasized the need for score-rating assessment of students educational success, motivating them to perfection (improvement) [10].

E. O. Rybakova (2012) considers the formation of personality sports culture by means of various sports [11,12].
In G. S. Sadykova's works (2005, 2008) humanization of technical universities students physical training as a basis of motivation increase for physical health means choice is considered. The basis of the author physical training concept is the implementation of an individual differentiated approach, stimulation and motivation to motor activity aimed at forming a conscious attitude to their own health $[13,14,15]$.

L. B. Shorokhova (2008) considers improvement of physical culture and sports popularization management as bases of the population of a healthy lifestyle values formation [16].

All of the above actualizes the need to consider the concept of technical universities students' physical health formation as the basis of the personality culture value orientation $[17,18,19]$.

\section{MATERIALS AND METHODS}

The article presents the author's material of studying the dynamics of the functional groups formation in the areas of physical education. Research of students groups formation process in the directions of carrying out occupations on physical education as the main, preparatory, special group usual and training medical physical culture is carried out. A questionnaire survey of students to identify the causes that affect the health of University students, their rank structure of external and internal factors.

\section{RESULTS AND DISCUSSION}

At the first stage of the study, the dynamics of University students distribution by functional groups was studied. Table 1 presents the results of the first-year students distribution analysis by functional health groups in the period from 2010 to 2018.

Table 1-Distribution of 1st year students by functional health groups

\begin{tabular}{|c|c|c|c|c|c|c|c|c|c|c|c|}
\hline \multirow{3}{*}{ Year } & \multirow{3}{*}{$\begin{array}{c}\text { Inspection } \\
\text { Chel. }\end{array}$} & \multicolumn{10}{|c|}{ Functional groups } \\
\hline & & \multicolumn{2}{|c|}{ Main } & \multicolumn{2}{|c|}{ Preparatory } & \multicolumn{2}{|c|}{ Special } & \multicolumn{2}{|c|}{$\begin{array}{c}\mathrm{E} \times \mathrm{e} \mathrm{r} \mathrm{c} \mathrm{i} \mathrm{s} \mathrm{e} \\
\text { therapy }\end{array}$} & \multicolumn{2}{|c|}{$\begin{array}{l}\text { Ex e r c i s e } \\
\text { t h e r a p y } \\
\text { (training) }\end{array}$} \\
\hline & & Chel & $\%$ & Chel & $\%$ & Chel & $\%$ & Chel & $\%$ & Chel & $\%$ \\
\hline 2010 & 1765 & 861 & 48,78 & 629 & 35,64 & 222 & 12,58 & 22 & 1,25 & 31 & 1,76 \\
\hline 2011 & 1365 & 825 & 60,44 & 384 & 28,13 & 124 & 9,08 & 8 & 0,59 & 24 & 1,76 \\
\hline 2012 & 1700 & 795 & 46,76 & 626 & 36,82 & 213 & 12,53 & 38 & 2,24 & 28 & 1,65 \\
\hline 2013 & 1396 & 684 & 49,00 & 550 & 39,40 & 129 & 9,24 & 6 & 0,43 & 27 & 1,93 \\
\hline 2014 & 1221 & 646 & 52,91 & 412 & 33,74 & 125 & 10,24 & 18 & 1,47 & 20 & 1,64 \\
\hline 2015 & 1269 & 712 & 56,11 & 384 & 30,26 & 142 & 11,19 & 15 & 1,18 & 16 & 1,26 \\
\hline 2016 & 1160 & 695 & 59,91 & 323 & 27,84 & 119 & 10,26 & 8 & 0,69 & 15 & 1,29 \\
\hline 2017 & 1192 & 624 & 52,35 & 420 & 35,23 & 122 & 10,23 & 7 & 0,59 & 19 & 1,59 \\
\hline 2018 & 1584 & 1073 & 67,74 & 374 & 23,61 & 114 & 7,20 & 7 & 0,44 & 16 & 1,01 \\
\hline
\end{tabular}

Note: exercise therapy physical culture; exercise therapy physical culture training 
Table 1 shows that during the study period there is a different dynamics of the students number belonging to the first functional group as the main one. There was an increase in the number of students assigned to the main group. For example, if in 2010 the number of students belonging to the main functional group was 861 people $(48.78 \%$ of the total number of examined students), in 2018 with the total number of examined students 1584 people, the number of students referred to the main functional group was 1073 people $(67.78 \%$ of the total number of examined students).

In 2010, 629 students (35.64\% of the total number of students) were assigned to the preparatory functional group. By 2018, there is a decrease in the number of students belonging to the preparatory group, to 374 people (23.61\%).

222 students $(12.58 \%$ of the total number of students) were assigned to the special functional group in 2010. By 2018, there is a decrease in the number of students belonging to the preparatory group, to 114 people ( $7.20 \%$ ).

In 2010, 22 students $(1.25 \%$ of the total number of students) were assigned to the functional group of therapeutic physical culture. By 2018, there is a decrease in the number of students belonging to this group to 7 students ( $0.44 \%)$.

In 2010,31 students $(1.76 \%$ of the total number of students) were enrolled in the functional group of training orientation therapeutic physical culture. By 2018 , there is a decrease in the number of students belonging to this group to 16 students (1.01\%).

In the dynamics of several years, there are periods when the ratio of the number of students assigned to different functional groups varies depending on various factors.

It is obvious that the role of physical culture and sports orientation innovative programs implementation is important.

The effectiveness of the physical culture and sports orientation innovative programs implementation is obvious.

Thus, studies of the functional groups formation dynamics for physical education clearly reflect the maximum level of functional deviations in the state of students health. The dynamism and reversibility of functional changes in the state of students health is observed. In this regard, there are large reserves for changing the ratio of functional groups in quantitative terms by reducing functional deviations.

On the one hand, we observe an increase in the growth rate of functional abnormalities and the incidence of chronic abnormalities. On the other hand, the inclusion in the daily life of students various programs of physical activity leads to an increase in the proportion of students belonging to the main and preparatory groups. The study of the students functional deviations structure allowed to obtain results characterizing the presence of more than three functional deviations.

The analysis of the research results allows us to note that the importance of sports and recreation programs used in the educational and extracurricular time of students increases. Section classes on sports and adaptive sports are updated among students. The concept of health acts as a comprehensive definition of the technical universities students functional state. The formation of students health culture from the first year acts as the basis of a healthy lifestyle, where the main factor are physical education programs of various directions.

On the basis of a questionnaire survey, we revealed the attitude of students to the components of the healthy lifestyle foundations (to the components of a healthy lifestyle)

The first-year students were presented with questionnaires, which listed the main components of a healthy lifestyle culture, such as physical culture and sports, the rules of proper nutrition, (proper nutrition) rest, physical activity, behavior.

Studies have shown that physical culture and sport as the basis of a healthy lifestyle occupy the first place (69\%). Compliance with the regime and rules of proper nutrition took three times place (22\%). In third place came rest, motor activity and behavior (9\%). Therefore, students, considering physical culture and sports as the basis of a healthy lifestyle culture, had in mind that there also includes motor activity.

Questions of a healthy lifestyle formation are also key in the system of students physical health. Issues of healthy lifestyle are also key in the system of students physical health formation. All students know that physical education classes are closely related to the physical and professional health of a person. The productivity of any activity depends on physical performance. Nevertheless, in universities, priority is given to classes of mental orientation. There are reasons aimed at the abolition of physical education classes, which significantly reduces the total amount of students physical activity (The abolition of physical education classes significantly reduces the total amount of students physical activity).

The questionnaire survey aimed at identifying the causes that negatively affect the state of health in the conditions of higher education and adaptation to the conditions of study at the University, showed the presence of external and internal causes.

Table 2 presents the rank structure of factors affecting the health of first-year students in the process of adaptation to University life. 
Table 2-Rank structure of factors influencing the health of first-year students in the process of adaptation to University life

\begin{tabular}{|c|c|c|}
\hline $\begin{array}{l}\text { Factors that affect students' } \\
\text { health }\end{array}$ & Importance (Rang) & Rank (\%) \\
\hline \multicolumn{3}{|c|}{ Internal factors } \\
\hline $\begin{array}{l}\text { Low knowledge about healthy } \\
\text { lifestyles }\end{array}$ & 1 & 27,3 \\
\hline $\begin{array}{l}\text { Lack of knowledge about healthy } \\
\text { lifestyles }\end{array}$ & 2 & 19,5 \\
\hline Physical fitness (Level) & 3 & 17,4 \\
\hline Low motor activity & 4 & 12,5 \\
\hline $\begin{array}{l}\text { Low level of motivation to } \\
\text { physical culture and sports }\end{array}$ & 5 & 11,8 \\
\hline Lack of mental fitness & 6 & 4.5 \\
\hline $\begin{array}{l}\text { Low level of communicative } \\
\text { qualities }\end{array}$ & 7 & 3,2 \\
\hline \multicolumn{3}{|c|}{ External factors } \\
\hline $\begin{array}{l}\text { Habits that negatively affect } \\
\text { health }\end{array}$ & 1 & 40,1 \\
\hline Family problems & 2 & 25,8 \\
\hline Training at the university & 3 & 20,3 \\
\hline Other factors & 4 & 11,6 \\
\hline
\end{tabular}

Table 2 shows that the most significant reason affecting the health of students is the lack of knowledge about healthy lifestyle with a ranking of $27.3 \%$. Consequently, school pays very little attention to the promotion of healthy lifestyles among older students. This can be explained by the fact that the graduating classes are preparing for the unified state examination. Of the external factors that negatively affect the health of students, the most significant are bad habits; the rank index was $40.1 \%$. Bad habits were classified as smoking, alcohol consumption, night life, disturbance regime, etc.

The health status of students is determined by their lifestyle. The way of students life in modern society has changed in the direction of increasing mental load to the detriment of motor activity. Lack of muscle activity has a negative impact on the health of students, leads to a decrease in both physical and mental performance, exacerbation of various chronic diseases.

Researches allow to develop the concept of student youth improvement at the expense of need formation to group and individual occupations of the physical culture and improving orientation.

The basic concept of students physical health formation is aimed at expansion of its intellectual, need-motivational and valuable components. All these components are formed by solving the following tasks:

- formation of theoretical knowledge and practical skills related to a healthy lifestyle;

- transformation of knowledge about healthy lifestyle to everyday life of students; application of knowledge about healthy lifestyle in everyday life of students;

- acquisition of self-control knowledge over the state of physical health;

- development of means and methods aimed at the formation and development of students physical health.

The main means of first-year students physical health forming was the inclusion of physical culture and recreation activities in the daily life of students.

A comprehensive study of various innovative techniques impact aimed at the implementation of varying intensity physical activity, will help to keep the physical and mental performance of students for a long time during the day.

A comprehensive study of various innovative techniques impact has shown that the implementation of varying intensity physical activity allows to keep the physical and mental performance of students during the day.

Morning physical exercises offered to students are affordable and easy to perform. Regular use of it provides toning of the central nervous system, improving the activity of body systems, increasing the adaptive capacity of the body to mental stress.

The main pedagogical conditions for the formation of technical universities students physical health can be the following: 
- use of integrative approach in application of sports means, physical culture and improving orientation; (in a choice of means)

- systematization of the funds use, taking into account the individual characteristics of the involved;

- organization of emotionally attractive classes in functional groups with limitations in the state of students health.

- scientific support of the students physical health formation process, which is key in the formation of training functional groups;

- implementation of an individual approach at all levels of physical culture classes organization;

- conducting sports-oriented activities with the implementation of the sports training principles.

\section{CONCLUSION}

The study of the dynamics of the functional groups formation in the conditions of University education requires the continuation of such work in order to control the physical health of students. The analysis of the research results allowed to implement the author's programs of the teaching staff. As follows from the results of in-depth medical examination of technical University students, it is possible to stop the negative trend of their health deterioration through the implementation of innovative physical education programs. An important factor in the deterioration of the students health is the intensification of educational process and its related stress, violation of diet, training and labour, social negative manifestations on the background of significant inactivity, etc. The study of the factors rank structure influencing the health status of students in the process of adapting to University life, and allows to correct the process of students physical health formation.

\section{REFERENCES}

1. Balsevich V.K., Lubysheva L.I., Progonyuk L.N. New vectors of children and teenagers mass physical education systems modernization in secondary school. Teoriya I praktika fizicheskoj kul'tury = Theory and practice of physical culture. 2003; 4: 56-59 (In Russ., In Engl.).

2. Balsevich V.K. Sport-oriented physical education: educational and social aspects. Teoriya I praktika fizicheskoj kul'tury = Theory and practice of physical culture. 2003; 5: 15-19 (In Russ., In Engl.).

3. Balsevich V.K., Lubysheva L.I. Theory and technology of sports-oriented physical education in mass secondary school. Fizicheskaya kul'tura: vospitanie, obrazovanie, trenirovka. 2005; 5: 50-53 (In Russ.).

4. Gavronina G.A., Kuznetsova Z.M. Dynamics of physical fitness of students engaged in physical culture on various educational programs. Teoriya I praktika fizicheskoj kul'tury = Theory and practice of physical culture. 2008; 11: 83-86 (In Russ., In Engl.).

5. Gavronina G.A., Gorbunov N.P. Features of the experimental program on physical education of students of special medical group. Sportivnoorientirovannaya sistema fizicheskogo vospitaniya - novaya pedagogicheskaya tehnologiya XXI veka. Sbornik materialov Vserossijskoj nauchnoprakticheskoj konferencii (5-7 aprelya 2007, Perm) [Sport-oriented system of physical education-a new pedagogical technology of the XXI century. Collection of materials of the all-Russian scientific and practical conference (5-7 April 2007, Perm)]. Perm. 2007: 56-59 (In Russ.).

6. Kolokoltsev M.M., Hambartsumyan R.A., Vlasov E.A. Efficiency of the extended motor mode in physical education of foreign students. Teoriya I praktika fizicheskoj kul'tury = Theory and practice of physical culture. 2014; 6: 18-20 (In Russ., In Engl.).

7. Kusakova R.F. Professional'no-prikladnaya fizicheskaya podgotovka studentov tehnicheskih vuzov: uchebnoe posobie [Professionally-applied physical training of students of technical colleges: textbook. manual]. Perm. state tech. UN-T.-Perm: PSTU. 2007: 117 (In Russ.).

8. Kusakova R.F. Primenenie raqstyagivayuchih uprazhnenij na zanyatiyah fizicheskoj kul'turoj: uchebnoe posobie [The Use of stretching exercises at the lessons of physical culture: textbook. manual]. Perm. state tech. UN-T. Perm: Publishing house of PSTU. 2008; 2: 236 (In Russ.).

9. Kusakova R.F. Fizicheskaya kul'tura studentov tehnicheskih vuzov: uchebnoe posobie [Physical culture of technical high schools students: textbook. manual]. Perm. state tech. Univ; Grif UMO of the Russian Federation. Perm: PSTU. 2008: 458 (In Russ.).

10. Nagovitsyn S.G. Physical culture in General cultural and professional training of nonphysical culture universities students. Fizicheskaya kul'tura, sport I zdorov'e nacii v XXI veke: materialy regional'noj nauchno-prakticheskoj konferencii [Physical culture, sport and health of the nation in the XXI century: materials of regional scientific and practical conference]. Arkhangelsk. 2010: 65-70 (In Russ.).

11. Rybakova E.O., Shutova T.N. Model of karate 11-13 years sports culture formation. Fizicheskaya kul'tura: vospitanie, obrazovanie, trenirovka. 2012; 1: 38-42 (In Russ.).

12. Rybakova E.O. Of the karate 11-13 years personality sports culture formation on the basis of the integral approach. Fizicheskaya kul'tura: vospitanie, obrazovanie, trenirovka. 2012; 5: 55-56 (In Russ.).

13. Sadykova G.S. Humanization of students 
physical education in higher technical educational institutions. Kazanskij pedagogicheskij zhurnal. 2008; 5: 97-105 (In Russ.).

14. Sadykova G.S., Galiev M.K., Notfullin I.R. Factors of health culture formation problems actualization. Vestnik Kamskogo Instituta. Nab. Chelny: Kama Institute. 2005: 72-73 (In Russ.).

15. Sadykova G.S., Mutaeva I.Sh. The Role of professional and applied physical training in physical education of Campi students. Vuzovskaya nauka proizvodstvu: sbornik materialov mezhvuzovskoj nauchno-prakticheskoj konferencii [University science and technology: collection of materials of interuniversity scientific and practical conference]. Neb. Chelny: Campi. 2005: 319-321 (In Russ.).

16. Shorokhova L.B. Improvement of physical culture and sports popularization management as one of preventive measures means against drugs. Deti Rossii obrazovanny I zdorovy: materialy VI Vserossijskoj nauchno-prakticheskoj konferencii
(Moskva, Aprel' 17-18, 2008) [Children of Russia are educated and healthy: materials of the VI allRussian scientific and practical conference (Moscow, April 17-18, 2008)]. 2008 (In Russ.).

17. Armstrong N., Welsman J.R. The physical activity patterns of European youth with reference to methods of assessment. Sports Medicine. 2006; 36: 1067-1086.

18. Craig C.L., Marshall A.L., Sjostrom M., Bauman A.E., Booth M.L., Ainsworth B.E., et al. International physical activity questionnaire: 12-country reliability and validity. Medicine and Sciences in Sports and Exercise. 2003; 35: 13811395.

19. Esculcas U., Mota J. Physical activity and leisure behaviors in adolescents: The influence of physical activity characteristics and the socioeconomic status. International Journal of Behavioral Medicine. 2000; 7: 208-213.

\section{Submitted: 20.08.2019}

Author's information:

Ildus G. Gibadullin - Doctor of Pedagogics, Professor, M.T. Kalashnikov State Technical University, 426069, Russia, Izhevsk, Studencheskaya str., House 7, e-mail: ffkis@istu.ru

Aleksandra Yu. Anisimova - Candidate of Pedagogics, Associate Professor, M.T. Kalashnikov State Technical University, 426069, Russia, Izhevsk, Studencheskaya str., House 7, e-mail: ffkis@istu.ru

Mikhail E. Ryabov - Senior Lecturer, M.T. Kalashnikov State Technical University, 426069, Russia, Izhevsk, Studencheskaya str., House 7, e-mail: ffkis@istu.ru

Yuriy A. Melnikov - Candidate of Pedagogics, Associate Professor, M.T. Kalashnikov State Technical University, 426069, Russia, Izhevsk, Studencheskaya str., House 7, e-mail: ffkis@istu.ru 